\title{
Prevalence, Characteristics, and Associated Risk Factors of Wrist Fractures in Americans Above 50: the Cross-sectional NHANES Study
}

\section{Juncai Ye}

Zhejiang University https://orcid.org/0000-0002-1927-9350

\section{Qiao Li}

Xinhua Hospital of zhejiang Province: The Second Affiliated Hospital of Zhejiang Chinese Medical University

Jing Nie ( $\square$ drjingnie@126.com )

Traumatology and Orthopedics hospital of Traditional Chinese Medicine of Xiaoshan District

\section{Research Article}

Keywords: wrist fracture, prevalence, NHANES, cross-sectional study

Posted Date: August 5th, 2021

DOI: https://doi.org/10.21203/rs.3.rs-751451/v1

License: (a) (1) This work is licensed under a Creative Commons Attribution 4.0 International License. Read Full License 


\section{Abstract}

\section{Background}

Wrist fractures, also known as distal radius fractures, are the most common fractures occurred in the upper limb. This study is conducted in the purpose of evaluating the prevalence, characteristics, and associated factors of wrist fractures in Americans that aged 50 and above.

\section{Methods}

Data of Americans aged 50 or above from the year 2013 to 2014 and 2017 to 2018 in NHANES was extracted and analyzed. Based on orthopedist's diagnosis, we further conducted surveys to determine the condition of wrist fractures, and collected relevant epidemiological and demographic data. The prevalence of wrist fractures and other statistics were calculated to study population characteristics and analyze potential risk factors associated with wrist fractures.

\section{Results}

The prevalence of wrist fractures among Americans whose age was 50 or above was $12 \%$, with similar results between men and women patients (male $12.8 \%$ vs female $11.4 \%, P=0.267$ ). Male and female Americans' first wrist fracture occurred at a mean age of 29.4. 17.8\% of Americans aged 50 and above had experienced two fractures, while $1.7 \%$ of Americans even experienced four or more fractures. The top two causes of the first fracture were falling down from standing height $(56 \%)$ and violent falls $(34.8 \%)$. Multivariate analysis showed that osteoporosis $(\mathrm{OR}=2.2,95 \% \mathrm{Cl}=1.7-2.9)$, excessive drinking $(\mathrm{OR}=1.8$, $95 \% \mathrm{Cl}=1.3-2.4)$, smoking $(\mathrm{OR}=1.6,95 \% \mathrm{Cl}=1.2-2.1)$, prednisolone administration $(\mathrm{OR}=1.5,95 \% \mathrm{Cl}=$ $1.1-2.1)$ and obesity $(\mathrm{OR}=0.8,95 \% \mathrm{Cl}=0.6-0.9)$ were independently associated with wrist fractures. Gender was not an independent risk factor associated with wrist fractures.

\section{Conclusions}

The prevalence of wrist fractures in Americans aged 50 and above was $12 \%$. The prevalence was similar between male and female patients. Falling from a standing height was the main cause of the first wrist fracture. Osteoporosis, excessive drinking, smoking and prednisolone administration were risk factors of wrist fractures, while obesity was negatively correlated.

\section{Introduction}

Wrist fracture is one of the most common fractures occurred in the United States, accounting for about one-sixth of all fractures treated in emergency departments. The prevalence of wrist fracture increases with age[1-4]. Studies have implied a significantly increased risk of recurrent wrist fractures within 7 years after the incidence of the initial wrist fracture. Risks of hip and vertebral fractures increased as well[5-7]. Fractures are usually followed by acute pain and swelling in the wrist and lead to dysfunction of wrist and even the quality of life if not being treated timely or appropriately $[8,9]$. There is also an 
increased risk of death following wrist fractures: within 5 years of the occurrence of distal fracture of the forearm, patients age 65 to 74 have a death risk of $13.1 \%$, while patients above 85 years old was $44.8 \%$ [10]. It is predicted that by the year 2040 , treatment cost for fractures would add up to $\$ 50$ billion, which adds the burden of the national health care system[11].

In the US., the incidence rate of wrist fractures were three times higher than that of hip fractures.

Therefore, even though the cost for hip fractures treatment per patient is higher, the overall treatment fee for wrist fractures excels hip and other fractures, which is why wrist fractures have drawn more attention from health care[ 7,12$]$. Therefore, it is high time that we design more studies to assess the prevalence, characteristics and associated risk factors of wrist fracture, contributing to their prevention and treatment measures. However, epidemiological studies on that incidence of wrist fractures were limited[5, 13]. There has not been reports on the prevalence of wrist fractures yet. Therefore, this study aimed to comprehensively investigate the prevalence, characteristics and related risk factors of wrist fracture among Americans aged 50 and above according to NHANES data from 2013 to 2014 and 2017 to 2018 . To the best of our knowledge, our study conducted the first research on patients with wrist fractures above 50 years of age based on data extracted from the NHANES database, which can enlighten the understanding for the disease as well as lending insight into prevention and improving prognosis.

\section{Methods}

\section{Study population}

The National Health and Nutrition Examination Survey (NHANES) is a bi-yearly stratified cross-sectional study of the population in the United States conducted by Centers for Disease Prevention and Control (CDC). NHANES was approved by the CDC for written informed consent from each participant. NHANES data are publicly available for use worldwide. The data of 19,429 Americans aged 50 or above from the year 2013 to 2014 and 2017 to 2018 NHANES was extracted to estimate the prevalence of wrist fractures among US civilian population aged $\geq 50$. All study subjects were examined physically and evaluated at medical centers. 13,587 subjects containing missing information on wrist fractures were excluded. The remaining 5,842 subjects, containing 554 wrist fracture cases ( male $n=239$, female $n=315$ ), were included into our study cohort.

\section{Study variables}

NHANES data were collected through standardized questionnaires and medical evaluation at medical centers. In combination with the epidemiological characteristics of previous wrist fractures and NHANES data variables, we collected the following variables of Americans aged 50 and above: age, gender, number of fractures onsets, the specific age and cause of the first wrist fracture; race (Mexican-American, Other Hispanic, Non-Hispanic White, Non-Hispanic Black, other race-including multi-racial), education (less than high school, high school or than), marital status, smoking history, drinking history, obesity, 
hypertension, diabetes, osteoporosis, medication history of prednisone or cortisone, and hip fracture history of parents. Participants were defined as high blood pressure patients if he complied at least one following condition: 1 . currently taking antihypertensive medications, 2 . previously diagnosed by a physician, 3. four blood pressure measurements indicated a mean systolic blood pressure $\geq 130 \mathrm{mmHg}$, 4. diastolic blood pressure $\geq 80 \mathrm{mmHg}[14]$. Obesity was defined if body mass index (BMI) $\geq 30[15]$. Diabetes was defined if the participant complied with at least one of the following conditions: 1. diagnosed by a physician, 2. currently taking hypoglycemic drugs, 3 . fasting blood glucose $\geq 130 \mathrm{mg} / \mathrm{dl}$, 4. glycated hemoglobin $\geq 6.5 \%[16]$. Kidney conditions were estimated based on the glomerular filtration rate in serum creatinine, eGFR $(\mathrm{mL} / \mathrm{min} / 1.73 \mathrm{~m} 2)=175 \times$ standardized Scr $-1.154 \times$ age $-0.203 \times 1.212$ [if black] $\times 0.742$ [if female][17]. EGFR $<60 \mathrm{~mL} / \mathrm{min} / 1.73 \mathrm{~m} 2$ were defined as chronic kidney disease (CKD), indicated by the Modification of Diet in Renal Disease (MDRD) Study [18]. Marital status included living alone (unmarried, separated, divorced, and widowed) and not living alone (living with a partner, married). All details of study variables in this study could be accessed in www.cdc.gov/nchs/nhanes.

\section{Statistical Analysis}

Considering the complex design of study of NHANES, we applied the survey package in R 4.0.5 to calculate sample-weighted prevalence and other statistics to study the population characteristics of American wrist fracture patients. Continuous variables were expressed as mean standard, enumeration data were expressed as percentage (\%), t-test was used for continuous variables, and chi-square test was used for categorical variables. In addition, variables such as age, gender, race, education, marital status, smoking, alcohol consumption, medication history of prednisone or cortisone, disease, and history of wrist fractures in the parents were applied in univariate analysis. The covariate with $P$ value $<0.20$ in univariate analysis was included in the multivariate logistic regression analysis to study risk factors related to wrist fracture. Statistical analysis was performed using $R$ ( $R$ package, version 4.0.5). $P<0.05$ (two-sided) were considered as statistically significant.

\section{Results}

\section{Clinical characteristics}

Clinical characteristics of the study population was displayed in Table 1. Men took up $46.5 \%$ of the total cases while women took up 53.5\%. The weighted mean age was 63.7. Races included Mexican American, Other Hispanic, Non-Hispanic White, Non-Hispanic Black, Other Races - Including Multi-Racial. Other characteristics included frequent drinking, non-smokers, current smoker, obesity, daily uptake of prednisone or cortisone, combination of osteoporosis, and parent history of wrist fractures. 
Table 1

Clinical characteristics of the study population

\begin{tabular}{|c|c|c|c|c|}
\hline Parameters & $\begin{array}{l}\text { Total } \\
\text { Mean or \% } \\
{[95 \% \text { Cl] }}\end{array}$ & $\begin{array}{l}\text { Nonfracture } \\
\text { Mean or \% } \\
{[95 \% \mathrm{Cl}]}\end{array}$ & $\begin{array}{l}\text { Fracture } \\
\text { Mean or \% } \\
{[95 \% \mathrm{Cl}]}\end{array}$ & $\begin{array}{l}\mathrm{p}- \\
\text { value }\end{array}$ \\
\hline $\mathrm{N}^{\star}$ & 5842 & 5288 & 554 & - \\
\hline Age(mean,years) & $63.7[63.2,64.2]$ & $63.7[63.2,64.2]$ & $63.8[62.7,64.9]$ & 0.8709 \\
\hline \multicolumn{5}{|l|}{$\operatorname{Sex}(\%)$} \\
\hline Male & $46.5[45.1,48]$ & $46.1[44.7,47.5]$ & $46.1[44.7,47.5]$ & 0.2676 \\
\hline Female & $53.5[52,54.9]]$ & $53.9[52.5,55.3]$ & $50.7[45,56.3]$ & 0.2676 \\
\hline \multicolumn{5}{|l|}{ Race (\%) } \\
\hline Mexican American & $5.4[3.9,7.4]$ & $5.7[4.1,7.8]$ & $3.4[1.8,6.3]$ & 0.0699 \\
\hline Other Hispanic & $4.7[3.8,5.8]$ & $4.9[4.0,6.1$ & $2.8[2.0,4.0]$ & 0.0014 \\
\hline Non-Hispanic White & $72[67.9,75.8]$ & $70.4[66,74.5]$ & $83.6[79.4,87]$ & $\hat{0}_{0.0001}$ \\
\hline Non-Hispanic Black & $10.2[8.2,12.5]$ & $10.7[8.6,13.3]$ & $5.9[4.5,7.7$ & 0.0001 \\
\hline Other Race - Including Multi-Racial & $7.7[6.3,9.5]$ & $10.7[8.6,13.3]$ & $5.9[4.5,7.7]$ & 0.0042 \\
\hline \multicolumn{5}{|l|}{ Marital status (\%) } \\
\hline Living alone & $33.9[31.9,35.9]$ & $35.3[32.9,37.7]$ & $35[30.7,39.5]$ & 0.9011 \\
\hline Not living alone & $36.7[34.9,38.5]$ & $64.7[62.3,67.1]$ & $65[60.5,69.3]$ & 0.9011 \\
\hline \multicolumn{5}{|l|}{ Level of education (\%) } \\
\hline Less than high school & $13.9[17.8,16.2]$ & $14.2[12,16.8]$ & $11.4[8.4,15.3]$ & 0.1985 \\
\hline High school or than & $86.1[80.7,91.6]$ & $85.8[79.7,91.9]$ & $88.6[78.0,99.5]$ & 0.1225 \\
\hline \multicolumn{5}{|l|}{ Drinking (\%) } \\
\hline Never & $32.3[29.7,35]$ & $32.7[30.2,35.3]$ & $29.5[23.6,36.1]$ & 0.2763 \\
\hline Occasional drink & $55.6[52.6,58.5]$ & $56.3[53.4,59.1]$ & $50.5[43.9,57.1]$ & 0.0607 \\
\hline Frequent drink & $12.1[10.7,13.7]$ & $11[9.8,12.4]$ & $20[15,26.3]$ & 0.0003 \\
\hline \multicolumn{5}{|l|}{ Smoking status (\%) } \\
\hline Never smoker & $53.5[50.7,56.3]$ & $54.9[52.3,57.5]$ & $43.3[35.7,51.1]$ & 0.003 \\
\hline Past smoker & $32.2[30.1,34.3]$ & $31.6[29.5,33.8]$ & $36.2[29.5,43.5]$ & 0.1823 \\
\hline
\end{tabular}




\begin{tabular}{|c|c|c|c|c|}
\hline \multirow[t]{2}{*}{ Parameters } & \multirow{2}{*}{$\begin{array}{l}\text { Total } \\
\text { Mean or \% } \\
{[95 \% \mathrm{Cl}]}\end{array}$} & \multirow{2}{*}{$\begin{array}{l}\text { Nonfracture } \\
\text { Mean or \% } \\
{[95 \% \mathrm{Cl}]}\end{array}$} & Fracture & \multirow{2}{*}{$\begin{array}{l}\mathrm{p}- \\
\text { value }\end{array}$} \\
\hline & & & $\begin{array}{l}\text { Mean or \% } \\
{[95 \% \mathrm{Cl}]}\end{array}$ & \\
\hline Current smoker & $14.3[12.6,16.3]$ & $13.5[11.8,15.3]$ & $20.5[15.9,26.1]$ & 0.0016 \\
\hline Obesity (\%) & $42[39.6,44.4]$ & $41.3[39,43.6]$ & $46.8[40.8,52.9]$ & 0.049 \\
\hline $\begin{array}{l}\text { Combined with chronic kidney } \\
\text { disease (\%) }\end{array}$ & $50.5[48.9,52.2]$ & $50.5[48.9,52.2]$ & $50.6[44.9,56.2]$ & 0.989 \\
\hline Combined with hypertension (\%) & $72.6[70.6,74.6$ & $72.6[70.3,74.7]$ & $72.9[66.7,78.3]$ & 0.9277 \\
\hline $\begin{array}{l}\text { Combined with diabetes diabetes } \\
\text { mellitus(\%) }\end{array}$ & $22[20.8,23.3]$ & $21.7[20.4,23.1]$ & $23.9[19.8,28.5]$ & 0.334 \\
\hline Combined with heart failure (\%) & $4.6[3.9,5.5]$ & $4.5[3.8,5.4]$ & $5.6[3.6,8.4]$ & 0.3034 \\
\hline Combined with stroke (\%) & $5.9[5.2,6.8]$ & $5.8[5,6.7]$ & $6.7[4.5,10]$ & 0.5205 \\
\hline $\begin{array}{l}\text { Every taken prednisone or cortisone } \\
\text { daily (\%) }\end{array}$ & $7.5[6.5,8.5]$ & $6.9[5.9,8.1]$ & $11.3[7.7,16.4]$ & 0.0345 \\
\hline Combined with osteoporosis (\%) & $10.4[9.1,11.8]$ & $9.3[8.2,10.5]$ & $18.4[13.6,24.5]$ & $<0.0001$ \\
\hline $\begin{array}{l}\text { History of Parents wrist fractures } \\
(\%)\end{array}$ & $17.2[15.7,18.7]$ & $83.5[81.7,85.2]$ & $77.6[73.3,81.4]$ & 0.0123 \\
\hline *Unweighted calculation & & & & \\
\hline
\end{tabular}

2. Population characteristics of wrist fractures from NHANES, 2013-2014 and 2017-2018

Among the total 5,842 US participants $\geq 50$ years of age, 554 patients with wrist fractures were identified via standard questionnaire described above. The prevalence of wrist fractures was $12 \%$, with similarities in men and women (male $12.8 \%$ vs female $11.4 \%, P=0.267$ ) (Fig. 1). Non-Hispanic White had the highest prevalence of $14 \%$ and there was significant difference in prevalence between Non-Hispanic White and other ethnic groups (Fig. 2). Male patients usually experienced a higher prevalence of the first wrist fractures under the age of 25 than women, while women had a higher prevalence than men once they reached the age of 50 (Fig. 3). Among the studied cases, the first fracture incidence occurred at a mean age of 29.4 , which was mostly caused by falling from standing height (56\%) or a violent fall $(34.8 \%)$. $17.8 \%$ of the studied population experienced a second wrist fracture, while $1.7 \%$ experienced four or more. However, there was no gender difference in the cause and frequency (Table 2). 
Table 2

Epidemiological characteristics of wrist fractures in the population aged 50 years or older

\begin{tabular}{|c|c|c|c|c|}
\hline Parameters & $\begin{array}{l}\text { Total } \\
\text { Mean or \% } \\
{[95 \% \text { Cl] }}\end{array}$ & $\begin{array}{l}\text { Male } \\
\text { Mean or \% } \\
{[95 \% \mathrm{Cl}]}\end{array}$ & $\begin{array}{l}\text { Female } \\
\text { Mean or \% } \\
{[95 \% \text { Cl] }}\end{array}$ & $\begin{array}{l}P \\
\text { value }\end{array}$ \\
\hline $\mathrm{N}^{*}$ & 554 & 239 & 315 & 0.029 \\
\hline $\begin{array}{l}\text { Age when } 1 \mathrm{st} \text { time wrist fracture } \\
\text { occurred (years) }\end{array}$ & $29.4[27.7,31.1]$ & $24.3[22.1,26.5]$ & $34.5[31.5,37.6]$ & $<.0001$ \\
\hline Factors of 1 st time wrist fracture (\%) & & & & 0.1028 \\
\hline A fall from standing height or less & $56[46.2,65.4]$ & $42.5[24.4,63]$ & $60[47.9,71.1]$ & \\
\hline A hard fall ${ }^{\star \star}$ & $34.8[26.7,43.8]$ & $38.1[24.7,53.5]$ & $33.8[23,46.7]$ & \\
\hline $\begin{array}{l}\text { A car accident or other severe } \\
\text { trauma }\end{array}$ & $8.5[4.6,15.3]$ & $17.6[7.2,36.9]$ & $5.8[2.9,11.2]$ & \\
\hline Don't know & $0.7[0.2,2.8]$ & $1.8[0.2,13.2]$ & $0.3[0,2.5]$ & \\
\hline Frequency of wrist fractures (\%) & & & & 0.3687 \\
\hline Twice & $17.8[11.2,27.3]$ & $15.7[8.6,32.6]$ & $19.9[12.1,33.1]$ & \\
\hline Three times & $5.5[3.4 .11 .2]$ & $5.6[1.9,17.8]$ & $5.4[2.2,12.4]$ & \\
\hline Four times or more & $2.2[0.9,5.2]$ & $2.5[0.6,10.3]$ & $1.9[0.8,4.1]$ & \\
\hline \multicolumn{5}{|l|}{ *Unweighted calculation } \\
\hline $\begin{array}{l}\text { **A hard fall such as falling off a la } \\
\text { for example, tripped, slipped, fell ou }\end{array}$ & step stool, & stairs;A fall & standing hei & less, \\
\hline
\end{tabular}

3. The relationship between each variable and wrist fracture

Univariate analysis of the wrist fractures and demographic characteristics of American men and women aged $\geq 50$ were showed (Table 3): There was no significant correlation between gender and wrist fracture $(P=0.914)$. Surprisingly, ethnic factors were correlated with the incidence of wrist fractures: compared to Mexican American, non-Hispanic Black were more likely to suffer from wrist fractures. Other correlated risk factors included frequent drinking, smoking, oral administration of glucocorticoids, concomitant osteoporosis, and fractures in family history and obesity. 
Table 3

univariate and multivariate analysis of Wrist Fracture

\begin{tabular}{|lll|}
\hline Parameters & Univariate analysis & Multivariate analysis \\
\hline Age & $1.0(1.0,1.0) 0.098$ & $1.0(1.0,1.0) 0.662$ \\
\hline Female & $1.0(0.8,1.2) 0.914$ & - \\
\hline Not living & $1.1(0.9,1.3) 0.538$ & - \\
\hline More than high school & $1.2(0.8,1.7) 0.310$ & - \\
\hline Occasional drink & $1.1(0.9,1.3) 0.413$ & $1.1(0.8,1.3) 0.656$ \\
\hline Frequent drink & $2.1(1.6,2.7)<0.001$ & $1.8(1.3,2.4)<0.001$ \\
\hline Past smoker & $1.4(1.2,1.8)<0.001$ & $1.2(1.0,1.5) 0.089$ \\
\hline Current smoker & $1.9(1.5,2.4)<0.001$ & $1.6(1.2,2.1)<0.001$ \\
\hline Combined with hypertension & $1.1(0.9,1.3) 0.525$ & - \\
\hline Combined with diabetes diabetes mellitus & $0.9(0.8,1.1) 0.529$ & - \\
\hline Combined with heart failure & $1.1(0.8,1.6) 0.509$ & - \\
\hline Combined with stroke & $1.2(0.9,1.7) 0.165$ & - \\
\hline Every taken prednisone or cortisone daily & $1.9(1.5,2.5)<0.001$ & $1.5(1.1,2.1) 0.011$ \\
\hline Combined with osteoporosis & $2.4(1.9,3.0)<0.001$ & $2.2(1.7,2.9)<0.001$ \\
\hline History of Parents wrist fractures & $1.4(1.1,1.8) 0.004$ & $1.1(0.8,1.4) 0.652$ \\
\hline Obesity & $1.3(1.1,1.5) 0.010$ & $0.8(0.6,0.9) 0.006$ \\
\hline Combined with chronic kidney diseases & $1.2(1.0,1.4) 0.071$ & $1.0(0.8,1.3) 0.886$ \\
\hline
\end{tabular}

Multivariate analysis of the wrist fractures and demographic characteristics of American men and women aged $\geq 50$ were showed (Table 3): frequent drinking $(\mathrm{OR}=1.8,95 \% \mathrm{Cl}=1.3-2.4, \mathrm{P}<0.001)$, smoking $(\mathrm{OR}=1.6,95 \% \mathrm{Cl}=1.2-2.1, \mathrm{P}<0.001)$, prednisolone administration $(\mathrm{OR}=1.5,95 \% \mathrm{Cl}=1.1-2.1$, $\mathrm{P}=0.011)$, osteoporosis $(\mathrm{OR}=2.2,95 \% \mathrm{Cl}=1.7-2.9, \mathrm{P}<0.001)$ were independent risk factors associated wrist fractures. However, obesity was not considered as a risk factor and obesity $(\mathrm{OR}=0.8,95 \% \mathrm{Cl}=0.6-$ $0.9, P=0.006$ ) in American men and women aged $\geq 50$ (Table 3 ).

\section{Discussion}

In the present cross-sectional study of 5,842 Americans $\geq 50$ years of age, the prevalence of wrist fractures was $12 \%$, without gender difference. Non-Hispanic whites had a higher risk of fractures than other races. Under the age of 25 , male patients usually experienced a higher prevalence of the first wrist 
fractures than women, while women had a higher prevalence than men after the age of 50 . It was discovered that falling from standing height was the main factor for wrist and forearm fracture. The population of patients with wrist fracture were found with frequent smoking, drinking history. The majority was also had a history of osteoporosis, prednisolone treatment, which accounted for a higher prevalence. However, obesity was not a positively related risk factor.

In 2000, WHO reported that the prevalence of wrist fracture in population age $\geq 50$ was $18.5 \%$ [19]. HyeYoung Kwon et al. suggested that the prevalence in Korea was $4.52 \%$ with no gender difference[20]. In a retrospective study of pediatric anterior wall fractures, the prevalence of forearm fractures in children aged 0 to 17 years was $24.1 \%$ in Washington, D.C[21]. In the Oslo Health Study conducted on 5,976 participants, the prevalence of anterior wall fractures $7.2 \%$ in men and $10.1 \%$ in women between the age of 59 and 60 , and men $9.1 \%$ and women 34.5\% between the age of 75 and 76[22]. The Study of Women's Health Across the Nation suggested that the prevalence of forearm fractures in postmenopausal women was $15 \%[23]$. The reason why these results differed from our result (prevalence of $12 \%$ ) might due to the different parameters included of the studied cases, such as ages, regions, and the initial occurrence time. Furthermore, we discovered that non-Hispanic whites had a higher risk of fracture, which was consistent with the results of a study of fracture risk in the diabetic population[24]. The higher risk that non-Hispanic whites experienced might be related to race-specific genes and dietary characteristics[25]. We also found that the incidence of the first wrist fracture after the age of 50 was higher in women than in men, which was supported by the Oslo Health Study[22]. Women ages above 50 are usually in or about to enter their menopause, who are at higher risk of osteoporosis that may lead to brittle fractures[6, 13, 26-28].

In addition, this study also showed that falling from standing height was a major contributing factor to forearm fractures (56.0\%), which was in line with the results reported by Norma J Mac Intyre and K C Chung[29, 30]. People in their adolescence (under the age of 25) are more exposed to various activities and movements that have potential danger of causing physical injuries, which included falling from the standing height[31-33]. Therefore, active anti-osteoporosis treatment and various effective measures for preventing falls, such as wearing non-slip shoes, avoiding slippery road surface and strengthening physical exercise, are vital for preventing forearm fracture.

Obesity, smoking, drinking alcohol, osteoporosis and usage of adrenal cortex hormones are common factors associated with fractures[4, 34, 35]. In our study, we have verified the positive correlation of wrist fractures with smoking, drinking, osteoporosis and prednisolone treatment. Smoking was an important risk factor for non-vertebral fracture in diabetic women, and the risk of non-vertebral fracture in diabetic women who have smoked is 3.47 times higher than that in non-smoking diabetic women[36]. Smoking can promote fracture by reducing bone mineral density in a dose-dependent manner[37]. Our study revealed that drinking alcohol also caused wrist fractures by affecting bone mineral density. Drinking alcohol was independently associated with an increased risk of forearm fractures and a dose-response relationship. Compared with non-drinkers, the RR for forearm fractures was 1.38 for women who drank greater than or equal to $25 \mathrm{~g}$ daily[38]. We further revealed the importance of smoking cessation and alcohol restriction for the prevention of hip fracture in the elderly. 
In a study conducted by Jason Lacombe et al. showed that a higher BMI was associated with a reduced risk of forearm and wrist neck fractures compared to women with an ideal BMl of 20.0 to $24.9 \mathrm{~kg} / \mathrm{m}^{2}$ [39]. The fact that a high $\mathrm{BMI}$ is protective and that weight loss appears to increase the risk of fractures may indicate an interaction between bone and fat[40]. However, the results in our study showed that obesity was negatively associated with wrist fractures: our results showed a $12 \%$ prevalence of wrist fractures in Americans aged 50 and above, without gender differences. Non-Hispanic whites were presented with a greater risk of bone fractures than other races. The incidence of the first wrist fracture after the age of 50 was higher in women than in men. Obesity, occasional smoking, frequent smoking, excessive drinking, osteoporosis, and prednisolone accounted for a higher proportion in the population with wrist fractures, which was positively correlated with wrist fractures. As far as we know, this is the first study to evaluate the prevalence of wrist fractures using NHANES data, which can provide the basis for the Ministry of Health to formulate measures for the prevention and treatment of wrist fractures.

Some limitations in this study should be addressed. First, this study could not avoid the parameters being associated with reporting bias and memory bias, such as the history of wrist fractures, medication history of prednisone or cortisone, smoking and drinking history. Second, due to the design of cross-sectional study, relative conclusion of causality couldn't be obtained. Finally, some variates which were closely related to fracture, such as exercise, BMD, and vitamin $\mathrm{D}$, were not considered as covariates because they contained too much missing values. Despite of the discussed limitations, the overall data collected from the NHANES database were reliable and had undergone sufficient validation to filter accurate individual samples to determine the prevalence.

\section{Conclusions}

In conclusion, our study demonstrated that the prevalence of wrist fractures in Americans aged 50 and above was $12 \%$. The prevalence was similar between male and female patients. Moreover, falling from a standing height was the main cause of the first wrist fracture. Osteoporosis, excessive drinking, smoking and prednisolone administration were risk factors, while obesity was negatively correlated with the prevalence of wrist fractures.

\section{Abbreviations}

NHANES: National Health and Nutrition Examination Survey; Cl: Confidence interval; OR: Odds ratio; BMI: Body mass index; EGFR: Estimate the glomerular filtration rate; CKD: Chronic kidney disease.

\section{Declarations}

\section{Acknowledgements}

We thank the NHANES data for being publicly available on the Internet for use by researchers worldwide. 
This study was designed by Jing Nie. Juncai Ye extracted the associated data from NHANES. Qiao Li performed statistical analysis. Juncai Ye and Qiao Li completed the composition of the manuscript. helped supervised the analysis, as well as revised and approved of the manuscript.

\section{Consent for publication}

All authors have agreed to publish the work on Journal of Orthopaedic Surgery and Research.

\section{Funding}

This study was not funded by any research funding.

\section{Availability of data and materials}

This research is a secondary analysis. Research data can be obtained from https://www.cdc.gov/nchs/nhanes/.

\section{Ethics approval and consent to participate}

This study does not contain any studies with human participants or animals performed by any of the authors. This study only involved secondary data analysis of the existing NHANES database, which is publicly available and has been de-identified, thus there is no need to apply an IRB approval from our own institution.

\section{Competing interests}

The authors declare that they have no competing interests.

\section{References}

1. Hanel DP, Jones MD, Trumble TE: Wrist fractures. Orthop Clin North Am 2002, 33(1):35-57, vii.

2. Black DM, Cooper C: Epidemiology of fractures and assessment of fracture risk. Clin Lab Med 2000, 20(3):439-453.

3. Cummings SR, Melton LJ: Epidemiology and outcomes of osteoporotic fractures. Lancet 2002, 359(9319):1761-1767.

4. Franic D, Verdenik I: Risk Factors for Osteoporosis in Postmenopausal Women - from The Point of View of Primary Care Gynecologist. Zdr Varst 2018, 57(1):33-38.

5. Crandall CJ, Hovey KM, Cauley JA, Andrews CA, Curtis JR, Wactawski-Wende J, Wright NC, Li W, LeBoff MS: Wrist Fracture and Risk of Subsequent Fracture: Findings from the Women's Health Initiative Study. J Bone Miner Res 2015, 30(11):2086-2095.

6. Cerocchi I, Ghera S, Gasbarra E, Feola M, Tarantino U: The clinical significance of wrist fracture in osteoporosis. Aging Clin Exp Res 2013, 25 Suppl 1:S81-82. 
7. Schousboe JT, Fink HA, Taylor BC, Stone KL, Hillier TA, Nevitt MC, Ensrud KE: Association between self-reported prior wrist fractures and risk of subsequent hip and radiographic vertebral fractures in older women: a prospective study. J Bone Miner Res 2005, 20(1):100-106.

8. Edwards BJ, Song J, Dunlop DD, Fink HA, Cauley JA: Functional decline after incident wrist fractures-Study of Osteoporotic Fractures: prospective cohort study. Bmj 2010, 341:c3324.

9. Hsu H, Fahrenkopf MP, Nallamothu SV: Wrist Fracture. In: StatPearls. Treasure Island (FL): StatPearls Publishing. Copyright @ 2021, StatPearls Publishing LLC.; 2021.

10. Curtis JR, Arora T, Matthews RS, Taylor A, Becker DJ, Colon-Emeric C, Kilgore ML, Morrisey MA, Saag KG, Safford MM et al: Is withholding osteoporosis medication after fracture sometimes rational? A comparison of the risk for second fracture versus death. J Am Med Dir Assoc 2010, 11(8):584-591.

11. Lane NE: Epidemiology, etiology, and diagnosis of osteoporosis. Am J Obstet Gynecol 2006, 194(2 Suppl):S3-11.

12. Pike $C$, Birnbaum HG, Schiller M, Sharma H, Burge R, Edgell ET: Direct and indirect costs of nonvertebral fracture patients with osteoporosis in the US. Pharmacoeconomics 2010, 28(5):395-409.

13. Wright NC, Hooker ER, Nielson CM, Ensrud KE, Harrison SL, Orwoll ES, Barrett-Connor E: The epidemiology of wrist fractures in older men: the Osteoporotic Fractures in Men (MrOS) study. Osteoporos Int 2018, 29(4):859-870.

14. Reboussin DM, Allen NB, Griswold ME, Guallar E, Hong Y, Lackland DT, Miller EPR, 3rd, Polonsky T, Thompson-Paul AM, Vupputuri S: Systematic Review for the 2017

ACC/AHAVAAPAABC/ACPM/AGS/APhA/ASH/ASPC/NMA/PCNA Guideline for the Prevention, Detection, Evaluation, and Management of High Blood Pressure in Adults: A Report of the American College of Cardiology/American Heart Association Task Force on Clinical Practice Guidelines. J Am Coll Cardiol 2018, 71(19):2176-2198.

15. Flegal KM, Ogden CL, Fryar C, Afful J, Klein R, Huang DT: Comparisons of Self-Reported and Measured Height and Weight, BMI, and Obesity Prevalence from National Surveys: 1999-2016. Obesity (Silver Spring) 2019, 27(10):1711-1719.

16. Carpenter DL, Gregg SR, Xu K, Buchman TG, Coopersmith CM: Prevalence and Impact of Unknown Diabetes in the ICU. Crit Care Med 2015, 43(12):e541-550.

17. Levey AS, Coresh J, Greene T, Stevens LA, Zhang YL, Hendriksen S, Kusek JW, Van Lente F: Using standardized serum creatinine values in the modification of diet in renal disease study equation for estimating glomerular filtration rate. Ann Intern Med 2006, 145(4):247-254.

18. Murphy D, McCulloch CE, Lin F, Banerjee T, Bragg-Gresham JL, Eberhardt MS, Morgenstern H, Pavkov ME, Saran R, Powe NR et al: Trends in Prevalence of Chronic Kidney Disease in the United States. Ann Intern Med 2016, 165(7):473-481.

19. Johnell O, Kanis JA: An estimate of the worldwide prevalence and disability associated with osteoporotic fractures. Osteoporos Int 2006, 17(12):1726-1733.

20. Kwon HY, Ha YC, Yoo Jl: Health-related Quality of Life in Accordance with Fracture History and Comorbidities in Korean Patients with Osteoporosis. J Bone Metab 2016, 23(4):199-206. 
21. Ryan LM, Teach SJ, Searcy K, Singer SA, Wood R, Wright JL, Chamberlain JM: Epidemiology of pediatric forearm fractures in Washington, DC. J Trauma 2010, 69(4 Suppl):S200-205.

22. Alver K, Meyer HE, Falch JA, Søgaard AJ: Outdoor air pollution, bone density and self-reported forearm fracture: the Oslo Health Study. Osteoporos Int 2010, 21(10):1751-1760.

23. Greendale GA, Huang M, Cauley JA, Harlow S, Finkelstein JS, Karlamangla AS: Premenopausal and early postmenopausal trabecular bone score (TBS) and fracture risk: Study of Women's Health Across the Nation (SWAN). Bone 2020, 140:115543.

24. Jain RK, Weiner MG, Zhao H, Williams KJ, Vokes T: Diabetes-Related Fracture Risk Is Different in African Americans Compared With Hispanics and Caucasians. J Clin Endocrinol Metab 2019, 104(11):5729-5736.

25. Curtis EM, van der Velde R, Moon RJ, van den Bergh JP, Geusens P, de Vries F, van Staa TP, Cooper C, Harvey NC: Epidemiology of fractures in the United Kingdom 1988-2012: Variation with age, sex, geography, ethnicity and socioeconomic status. Bone 2016, 87:19-26.

26. Masud T, Jordan D, Hosking DJ: Distal forearm fracture history in an older community-dwelling population: the Nottingham Community Osteoporosis (NOCOS) study. Age Ageing 2001, 30(3):255258.

27. Haentjens P, Johnell O, Kanis JA, Bouillon R, Cooper C, Lamraski G, Vanderschueren D, Kaufman JM, Boonen S: Evidence from data searches and life-table analyses for gender-related differences in absolute risk of hip fracture after Colles' or spine fracture: Colles' fracture as an early and sensitive marker of skeletal fragility in white men. J Bone Miner Res 2004, 19(12):1933-1944.

28. Beringer TR, Finch M, Mc ATH, Whitehead E, Keegan DA, Kelly J, Lee G, McKane R, McNally C, McQuilken M: A study of bone mineral density in women with forearm fracture in Northern Ireland. Osteoporos Int 2005, 16(4):430-434.

29. Maclntyre NJ, Dewan N: Epidemiology of distal radius fractures and factors predicting risk and prognosis. J Hand Ther 2016, 29(2):136-145.

30. Chung KC, Spilson SV: The frequency and epidemiology of hand and forearm fractures in the United States. J Hand Surg Am 2001, 26(5):908-915.

31. Earnshaw SA, Cawte SA, Worley A, Hosking DJ: Colles' fracture of the wrist as an indicator of underlying osteoporosis in postmenopausal women: a prospective study of bone mineral density and bone turnover rate. Osteoporos Int 1998, 8(1):53-60.

32. Vogt MT, Cauley JA, Tomaino MM, Stone K, Williams JR, Herndon JH: Distal radius fractures in older women: a 10-year follow-up study of descriptive characteristics and risk factors. The study of osteoporotic fractures. J Am Geriatr Soc 2002, 50(1):97-103.

33. Diamantopoulos AP, Rohde G, Johnsrud I, Skoie IM, Hochberg M, Haugeberg G: The epidemiology of low- and high-energy distal radius fracture in middle-aged and elderly men and women in Southern Norway. PLoS One 2012, 7(8):e43367.

34. De Laet C, Kanis JA, Odén A, Johanson H, Johnell O, Delmas P, Eisman JA, Kroger H, Fujiwara S, Garnero P et al: Body mass index as a predictor of fracture risk: a meta-analysis. Osteoporos 
Int 2005, 16(11):1330-1338.

35. Hemenway D, Azrael DR, Rimm EB, Feskanich D, Willett WC: Risk factors for wrist fracture: effect of age, cigarettes, alcohol, body height, relative weight, and handedness on the risk for distal forearm fractures in men. Am J Epidemio/ 1994, 140(4):361-367.

36. Jørgensen L, Joakimsen R, Ahmed L, Størmer J, Jacobsen BK: Smoking is a strong risk factor for non-vertebral fractures in women with diabetes: the Troms $\varnothing$ Study. Osteoporos Int 2011, 22(4):12471253.

37. Ward KD, Klesges RC: A meta-analysis of the effects of cigarette smoking on bone mineral density. Calcif Tissue Int 2001, 68(5):259-270.

38. Hernandez-Avila M, Colditz GA, Stampfer MJ, Rosner B, Speizer FE, Willett WC: Caffeine, moderate alcohol intake, and risk of fractures of the hip and forearm in middle-aged women. Am J Clin Nutr 1991, 54(1):157-163.

39. Lacombe J, Cairns BJ, Green J, Reeves GK, Beral V, Armstrong MEG: The Effects of Age, Adiposity, and Physical Activity on the Risk of Seven Site-Specific Fractures in Postmenopausal Women. $J$ Bone Miner Res 2016, 31(8):1559-1568.

40. Billington EO, Gamble GD, Reid IR: Parathyroid hormone reflects adiposity and cardiometabolic indices but not bone density in normal men. Bonekey Rep 2016, 5:852.

Figures 


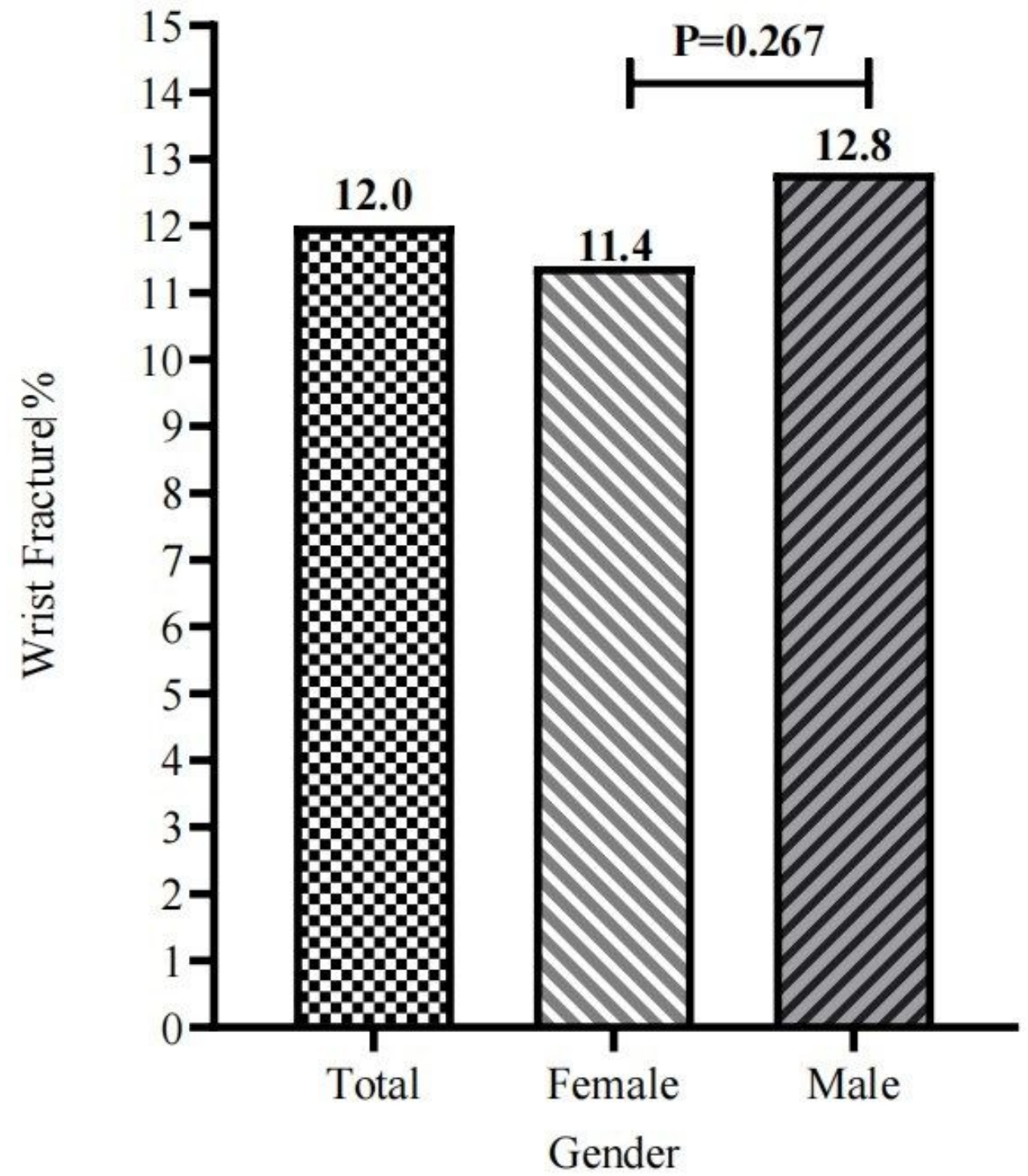

\begin{tabular}{|l|l|l|l|l|}
\hline Sex & Total & Male & Female & P value \\
\hline Wrist & & & & \\
Fracture \% & $12.0[10.7,13.5]$ & $12.8[10.8,15.0]$ & $11.4[9.9,13.2]$ & 0.267 \\
{$[95 \% \mathrm{CI}]$} & & & & \\
\hline
\end{tabular}

Figure 1

Relationship between gender and prevalence of wrist fractures. 


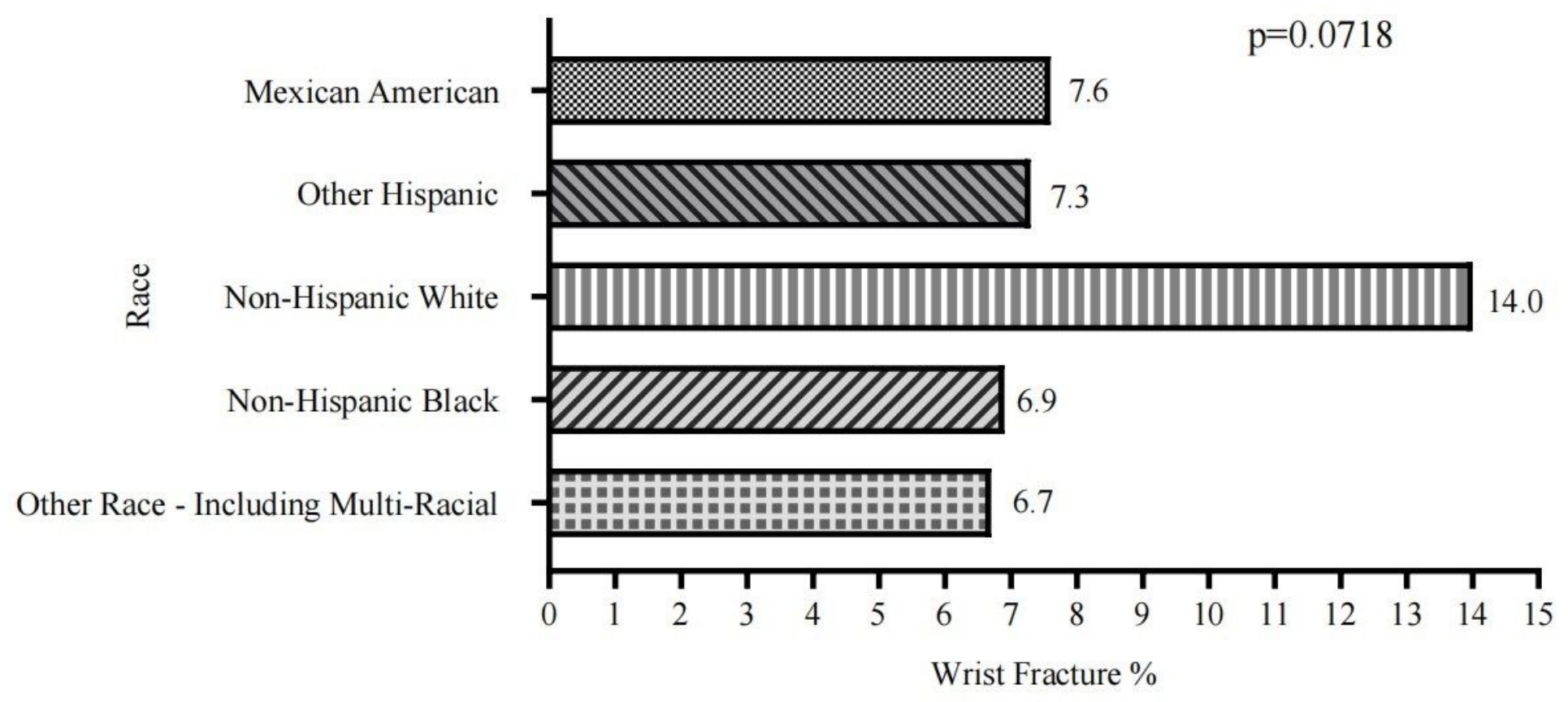

\begin{tabular}{|l|l|l|l|l|l|l|}
\hline Race & $\begin{array}{l}\text { Mexican- } \\
\text { American }\end{array}$ & Other & Hispanic & Non- & Non- & Other Race- \\
White & Black & Multi-Racial & \\
\hline Wrist & $7.6[4.5,12.7$ & $7.3[5.7,9$ & $14.0[12.2$, & $6.9[5.4,8$ & $6.7[4.3,10.3]$ & 0.0718 \\
Fracture \% & ] & $.3]$ & $16.0]$ & $.8]$ & & \\
{$[95 \% \mathrm{CI}]$} & ] & & & & & \\
\hline
\end{tabular}

Figure 2

Relationship between race and prevalence of wrist fractures. 


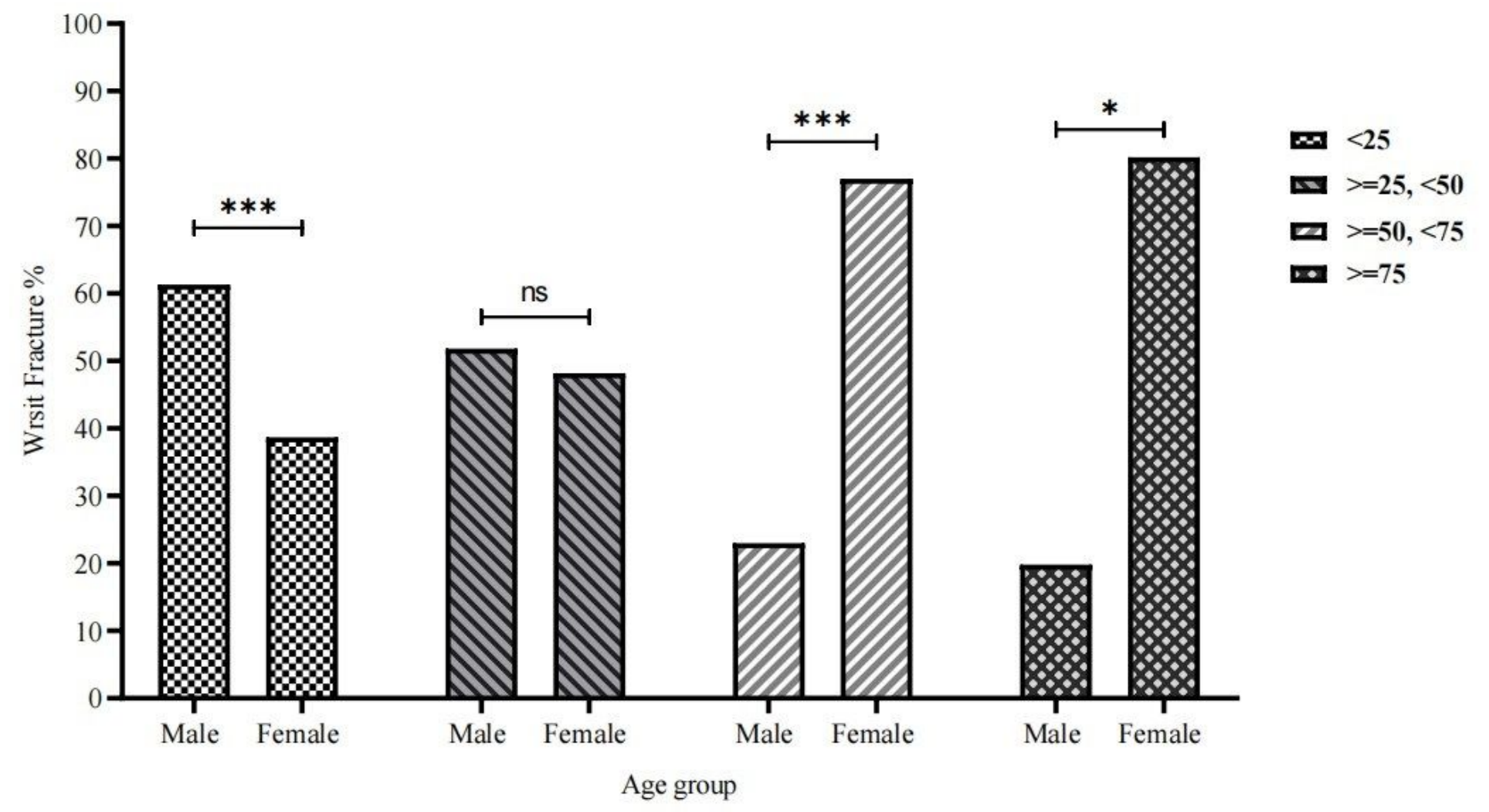

\begin{tabular}{|l|l|l|l|l|l|}
\hline Age group, & $<25$ & $>=25,<50$ & $>=50,<75$ & $>=75$ & $p$ for trend \\
\hline Male \%[95\% & $61.3[52.4$, & $51.8[40.2$, & $23.0[15.8,3$ & $19.8[2.0,7$ & \\
$\mathrm{CI}]$ & $69.5]$ & $63.3]$ & $2.2]$ & $4.9]$ & $<0.0001$ \\
\hline Female \%[95 & $38.7[30.5$, & $48.2[36.7$, & $77.0[67.8,8$ & $80.2[25.1$, & \\
$\% \mathrm{CI}]$ & $47.6]$ & $59.8]$ & $4.2]$ & $98.0]$ & $<0.0001$ \\
\hline $\mathrm{p}$-value & 0.0001 & 0.603 & $<0.0001$ & 0.0255 & \\
\hline
\end{tabular}

Figure 3

Relationship between gender and first occurrence of wrist fracture in different age groups. 